\title{
ПРОТИВОРЕЧИВОСТЬ ЦЕННОСТНО-НОРМАТИВНОЙ РЕГУЛЯЦИИ ВЗАИМОДЕЙСТВИЯ ТЕХНОГЕННОГО ОБЩЕСТВА И ПРИРОДЫ
}

\section{INCONSISTENCY OF THE VALUE-NORMATIVE REGULATION OF INTERACTION TECHNOGENIC SOCIETY AND NATURE}

\section{A. Svidersky}

Summary: The object of the study is the genesis of the value-normative system. The study involves the analysis of the correlation of value and normative mechanisms of regulation of material-transformative activity as a central element of interaction between society and nature. The contradictions of the object under consideration due to the specifics of socio-technogenic development are revealed.

Keywords: axiology, social norm, technogenic society, value-normative system, value.
$\Pi$ роблемным полем социокультурной регуляции деятельности всегда является приоритетное соотношение ценностных и нормативных механизмов регуляции. Известно, что, будучи тесно взаимосвязанными, включенными в единый регулятивный комплекс культуры, ценности и нормы регулируют деятельность человека по-разному. В отличие от ценности в нормах в наибольшей степени проявлен внешне-ограничительный аспект регуляции. Так возникает известное противоречие между ценностно-целевым направлением человеческой воли и рамками, препятствиями для её реализации, которые устанавливает социальная норма.

Если интегральной характеристикой развития человечества, следуя гегелевской традиции, мы определяем постоянное возрастание индивидуальной свободы. То, общей тенденцией эволюции ценностно-нормативной системы взаимодействия общества и природы является усиление в ней ценностного компонента. Но, если эту проблему анализировать в контексте развития индустриально-техногенного и постиндустриально-техногенного общества, то можно обнаружить, что в структуре деятельности трансформируется роль её компонентов. Целеполагающий субъект поступательно утрачивает позицию детерминанты человеческой активности, а основанием деятельности совершенно не обязательно является осознанное основание - мотив. Процессуальность активности задается не практическим мышлением субъекта деятельности, а внешними
Свидерский Александр Александрович старший преподаватель, Брянский государственный аграрный университет filos.as@yandex.ru

Аннотация: 0бъектом исследования выступает генезис ценностно-нормативной системы. Исследование предполагает анализ соотношения ценностных и нормативных механизмов регуляции материально-преобразовательной деятельности как центрального элемента взаимодействия общества и природы. Выявлены противоречия рассматриваемого объекта, обусловленные спецификой социально-техногенного развития.

Ключевые слова: аксиология, социальная норма, техногенное общество, ценностно-нормативная система, ценность.

для его воли алгоритмами действий-операций, следование которым также не может быть предметом выбора. Участвуя в социо-техническом взаимодействии индивид фактически подменяет социальные нормы техническими [1, с. 133], которые, в свою очередь, воспринимаются им как квазисоциальные, как возможная и эффективная замена социальных норм. Но, техническая норма практически лишена аксиологической основы, здесь техническая целесообразность нивелирует любой ценностно-смысловой контекст.

Коллизия соотношения ценностного и нормативного регулирования деятельности раскрывается в осмыслении развивающихся форм отчуждения, которые нарушают межсубъективные ценностные отношения и препятствуют творческому воспроизводству ценностей в культуре. Одной из форм ценностного отчуждения характерных для техногенного общества можно считать разрыв естественных, жизненных связей человека и природы, которая выступает не только средой, необходимым условием человеческой жизнедеятельности, объектом-носителем ценностных свойств, но и полноценным субъектом ценности, как источник земной жизни, как естественная основа человека и условие бытия его духа. Здесь уместно вспомнить знаменитое высказывание Кондрата Лоуренса о том, что разрушая природу мы уничтожаем культуру, ценности [2, с. 51].

Формирование межсубъективных ценностных свя- 
зей не представляет собой функцию социума, а возникает в процессе достаточно тонкого индивидуального встраивания в субъекта. Прежде всего, индивид должен обнаружить во внешней и внутренней природе субъективное начало, а для этого обязательно почувствовать в ней некую сообразность себе, одухотворить и деобъективировать. Здесь важно понимать, что ценностные взаимоотношения с природой не являются биологически запрограммированными, это есть естественно-культурное отношение, отражающее естественную укорененность человека в природе, раскрытую культурой.

В парадигме развития техногенного общества, экспансия технических средств и технологий экранирует природное, которое в этой ситуации выступает лишь объектом социо-технического воздействия. Николай Бердяев отмечает: «Об объектах образуют понятия, но к объектам не может быть приобщения» [3, с. 248]. Объективирование природы, исключает эмоциональное переживание, чувствование, которое, собственно, и порождает ценностно-смысловой контекст существования. Так сегодня мы видим множество ценностных деклараций, которые не имеют никакого отношения к реальному способу деятельности людей.

Объективирование природы в техногенном обществе опирается на техническую рациональность в которой природа выступает материалом для преобразования, усовершенствования, исправления. Причем, в силу общих тенденций развития техногенного общества, техническая рациональность успешно опирается на антропоцентрическое мировоззрение и абстрактный гуманизм, в том числе современный трансгуманизм. Антропоцентрическая ценностная иерархия постулирует аксиологическую, гносеологическую и этическую доминанту индивида в универсуме, для которого, собственно, и существует природа и без него невозможна. Человек здесь, как телесное существо считает себя высшим продуктом природы, и в этом смысле ее целью.

Нивелирование акиологического смысла природного, естественного в окружающем мире и в самом человеке, когда естество предстает как антиценность («вместилище зла») или ценностный смысл нейтрализован («пустота») означает отчуждение человека от природы и формирование антикультуры, развитие которой сопровождается значительными внутренними системными кризисами и возникновением острых противоречий в системе «общество-природа» (прежде всего экологических проблем).

Рассматривая перспективы нормативного регулирования преобразующей деятельности в условиях нарастающего аксиологического вакуума и кризиса субъекта, присущих современному техногенному обществу, необходимо проанализировать историческое развитие нормативных систем регулирующих природопользование. Известно, что в первобытном обществе материально-преобразовательная деятельность человека была жестко регламентирована суггестивно внедряемыми нормами, а в ряде своих аспектов табуирована. Но, общий характер эволюции нормативной системы, регулирующей взаимодействие традиционного общества и природы, проявляется в постоянном сокращении сферы действия правил, ограничивающих преобразовательную активность. Не смотря на то, что уже в Древнем мире происходит осознание необходимости правовой регуляции природопользования и в древнейших правовых памятниках мы встречаем нормы посвященные охране природы, мы не имеем дела с собственно экологическими нормами, так как вышеназванные нормы были обусловлены социально-экономическими интересами привилегированных слоев.

В техногенном обществе, за два прошедших столетия можно наблюдать поступательное расширение поля правового регулирования различных аспектов взаимодействия техногенного общества и природы. Это объясняется значительным усложнением социальных систем и трансформацией их в направлении социо-технической системы.

Экологизация современного права была вызвана не только соответствующими изменениями в состоянии окружающей среды, обусловившими возникновение глобального экологического кризиса, но и общими тенденциями развития культуры. Как показывают наши исследования[4,5], экологизация норм права только начавшийся процесс, отражающий общую тенденцию экологизации современной культуры. Сущность же экологизации норм права заключается в приведении их в соответствие с экологическими ценностями, то есть включение правовых норм в единый ценностно-нормативный механизм регуляции материально-преобразовательной деятельности.

Достаточно болезненный процесс утверждения в различных странах экологического права, призванного регулировать комплекс общественных отношений в сфере взаимодействия общества и природы в национальном или международном масштабе, вызывает мощную критику его оснований, содержания, направленности. Причем в большинстве случаев подчеркивается настоятельная необходимость усиления запретительного характера нормативного предписания, жесткости применения нормы, создания мощного института формализованного контроля за исполнением норм экологического права.

Идеализация аскетизма и созерцательности присущих традиционному обществу наталкивает исследователей на поиск ответов в сфере традиционных религи- 
озных систем. Их неоспоримым достоинством является то обстоятельство, что они обращены к человеку, как к универсальному проблемному полю, а соответственно поиск природы экологических неурядиц современности во внутренних константах человеческого бытия. Но при этом они заведомо ограничивают его самостоятельность, способность активно реагировать на возникшие проблемы.

Указание на несовершенство человеческой природы, которое проявляется в его воздействии на среду, становится распространенным и в нетеологических концепциях, представители которых также склонны обвинять и обличать человечество, отстаивая тезис о презумпции виновности человека перед природой. Отрицание позитивных сторон человеческой природы логически приводит нас к идее невозможности каким-либо образом повлиять на экологическую проблему, а значит, ведет к экофинализму.

Заметное усиление зависимости современного техногенного общества от природы, в условиях нарастания глобального социо-природного кризиса, вопреки декларируемой автономности, порождает естественные мысленные аналогии с первобытным обществом, в котором колоссальная зависимость от природы табуировало взаимоотношение своих членов с природным окружением. В.А. Зубаков полагает, что «каждый гражданин Дома Земля должен в день своего совершеннолетия пройти инициацию и принять на себя строжайшие Табу, запрещающие ему предпринимать любые действия, могущие нанести вред Биосфере и другим людям» [6, с.150] Действительно, в условиях нарастания экологического кризиса биосфера становится настолько хрупкой, что действия даже одного человека, использующего тех- нические средства, могут нанести непоправимый вред биологическим системам. Идейно понятный пафос экологов находит отражение в запретительном характере современного нормотворчества. Но сегодня эти барьеры уже не являются непреодолимыми.

Здесь необходимо учитывать, что все виды социальных норм, нормативной регуляции функционируют как правило, не обособленно, а в системном взаимодействии, в комплексе. Таким образом, признание исключительной роли правовых норм и санкций в регулировании кризисных процессов во взаимодействии общества и природы, вне связи с единым комплексом социокультурной регуляции, делает нормы экологического права неэффективными, сугубо внешними, чуждыми для субъектов права.

Правовая практика показывает, что право опирающееся на принудительные санкции государства не является эффективным средством налаживания экологической деятельности и экологического производства. Подчеркивание ведущей роли государственного принуждения или даже физического насилия в решении проблем, как на национальном, так и на международном уровне не соответствует не только общим тенденциям развития культуры, но и тем целям, которым должны служить экологическое право и экологическая политика, не способствуют выживанию человечества. «Мир не станет лучше, если пытаться изменить его с помощью насилия, - утверждал А. Печчеи, - это могут сделать только исключающие насилие методы и подходы»[7, с. 224]. Как известно, насилие порождает насилие и углубляет отчуждение, под какими лозунгами оно бы не преподносилось. Страх, вызванный насилием, ещё больше отчуждает и препятствует формированию ценностных отношений.

\section{ЛИТЕРАТУРА}

1. Шустов А.Ф. Гуманистическая ориентация развития технической деятельности// Труды инженерно-технологического факультета Брянского государственного аграрного университета № 1, 2021 С. 129-147.

2. Лоренц К. Восемь смертных грехов цивилизованного человечества // Вопросы философии. - 1992. - №3. - С. 51.

3. Бердяев Н.А. Философия свободного духа. М., 1994. 479 с.

4. Свидерский А.А. Социокультурная обусловленность отчуждения общества от природы // Вестник Брянской государственной аграрной академии.2015.№1.С 9-13.

5. Свидерский А.А. // Вестник Брянской государственной аграрной академии.2015.№4.С 14-18.

6. Зубаков В.А. Куда идем: к экокатастрофе или экореволюции // Философия и общество.- 2001.- №4.- С. 127-155

7. Печчеи А. Человеческие качества. М., 1985. 312 с.

(с Свидерский Александр Александрович (filos.as@yandex.ru).

Журнал «Современная наука: актуальные проблемы теории и практики» 